\title{
Tchaikovsky'nin Manfred ve 4. Senfonilerinin Viyolonsel Partisindeki Hızlı Pasajlara Yönelik Teknik Öneriler
}

\author{
Passages That Require Agility in the Cello Parts of Tchaikovsky's \\ Manfred and Symphony No. 4
}

\author{
Ayşem ERSOY ${ }^{1}$ (])
}

DOI: 10.26650/CONS2021-996136

'İstanbul Üniversitesi, Devlet Konservatuvarı, İstanbul, Türkiye

ORCID: A.E. 0000-0003-2137-3642

\section{Sorumlu yazar/Corresponding author: Ayşem ERSOY, \\ İstanbul Üniversitesi, Devlet Konservatuvarı, İstanbul, Türkiye \\ E-posta/E-mail: aysemersoy@gmail.com}

Başvuru/Submitted: 15.09.2021

ilk Revizyon/Revision Requested: 10.12.2021 Son Revizyon/Last Revision Requested: 16.12.2021

Kabul/Accepted: 23.12 .2021

Online Yayın/Published Online: 00.00 .0000

Atıf/Citation: Ersoy, A. (2021). Tchaikovsky'nin Manfred ve 4. senfonilerinin viyolonsel partisindeki hızlı pasajlara yönelik teknik öneriler. Konservatoryum - Conservatorium, 8(2), 253-279.

https://doi.org/10.26650/CONS2021-996136 öz

Bu çalışmada, Tchaikovsky'nin Manfred ve 4. Senfonileri'nin viyolonsel partisinin icrası sırasında hızlı pasajlarda sol el anatomisi gereğince yaşanan ajilite ve artikülasyon problemlerini gidermeye yönelik çözüm önerileri ve egzersizler sunulmaktadır. Bunun öncesinde ise çalgı eğitimindeki bilişsel yöntemler tartışılmaktadır. Bu bilişsel yöntemler, istenmeden bilinçsizce gelişmiş olumsuz düşünce sistemlerini değiştirmeye yönelik yeniden yapılandırmayı amaçlayan çalışmalardır. Bunun için, zihinsel imgeleme kullanılarak belirli bir tecrübeyi bilinçli bir şekilde zihinde canlandırma çalışması yapııır. Bu bağlamda, imgeleme ve davranış yöntemlerinin performansta ne kadar önemli olduğu konu edilmiş ve daha sonra müzisyenler tarafından uygulanan çeşitli fiziksel terapi teknikleri incelenmiştir. Bunlar arasında en bilinenlerinden olan Alexander tekniği ve Feldenkrais metoduyla ilgili bir literatür taraması yapılmıştır. Ardından performans öncesinde zihinsel ve fiziksel hazırlık için yoga ve meditasyon gibi yöntemlere, özellikle de bu çalışmaya konu olan sol el anatomisi hakkında bilgiler derlenmiştir. Bu çalışmaya konu olan Manfred ve 4. Senfonileri'ndeki viyolonsel partisinin hızlı pasajları için duateleri ve pozisyon geçişlerini doğru kullanabilmeye yönelik egzersiz örnekleri performans uygulaması açısından sunulmuştur.

Anahtar Kelimeler: İcra, Viyolonsel, Tchaikovsky

\section{ABSTRACT}

This paper presents suggestions and exercises to solve the problems related to agility and articulation due to the anatomy of the left hand while performing the cello parts of Tchaikovsky's Manfred Symphony and Symphony No. 4. The cognitive methods in instrument training are explored in this study. These cognitive methods are studies aimed at restructuring the unintentionally developed negative thought systems. A certain experience is consciously visualized in the brain using mental imagery. In this context, the importance of imagery and behavioral methods in performance is presented. This study examined various physical therapy techniques applied by musicians, including the Alexander technique and the Feldenkrais method - two of the most wellknown methods. The discussion also focuses on methods such as yoga and 
meditation that are used for mental and physical preparation in addition to left-hand anatomy, left-hand pattern, articulation, and agility. Finally, the paper provides exercise examples on the correct use of fingering and position transitions for the fast passages of the cello parts in Manfred and Symphony No. 4 in performance practices.

Keywords: Performance, Cello, Tchaikovsky

\section{EXTENDED ABSTRACT}

This study aims to provide solutions by suggesting exercises for agitation and articulation problems in the cello passages of two of Tchaikovsky's symphonies: Manfred and the Symphony No. 4. Playing an instrument is a difficult and complex process that requires tactile, auditory, and visual coordination. This complex process requires the evaluation of the ongoing performance and the immediate correction of the good or bad auditory, tactile, and visual stimuli occurring simultaneously. During the performance, physically straining the body with an incorrect seating technique tends to cause the person to develop pathological performance habits that lead to injuries. A person who does not advance enough technically begins to have problems not only in individual instrument studies but also in difficult passages that they encounter in instrument ensembles, such as orchestra and chamber music. In order to advance with the right technique in instrument training, one must first discover and improve their physical and mental awareness and have the ability to use this awareness in the performance phase. Mistakes that occur during the performance sometimes affect the emotional state of the performer and can cause tension, anxiety, and muscle strain.

Considering the difficulties faced by cellists in the technically challenging passages in the cello parts of Tchaikovsky's Manfred and Symphony No. 4, this article suggests techniques and exercises to overcome these difficulties. One of the exercise methods that can be practiced before the performance is the Alexander technique. This technique is defined as a re-learning method that helps relieve tensions in the body by preventing many movements that have become habitual for the performer over time without being noticed. This technique emerged after a long period of self-monitoring by the Australian actor Frederick Matthias Alexander (1869-1955) when he suffered voice loss on stage and doctors were unable to find a cure. "Bodily intelligence" (kinesthetic sense), a term Alexander uses in his technique, sends the movements in the muscles and joints as a message to the brain.

Another technique discussed is the Feldenkrais method devised by Moshe Feldenkrais. He created this method upon seeking an alternative solution to having an operation after 
sustaining repeated injuries (Dilekli, 2019, p. 22). It is built on the principles of physics, biomechanics, neuroscience, the neuromuscular system, and learning approach. A goal of this method is to expand self-image through sequences of movements focusing on parts of the body that are outside one's realm of awareness.

The benefits of yoga and meditation, which keep stress and tension under control, are mentioned in this paper. Yoga is a good preparatory lesson for music education because it is accompanied by physical warming up, flexibility, relaxation, and strengthening of the muscles; concentrating on the movements and balance of the body; and regular and deep breathing during the applied movements. While doing yoga, the body releases serotonin and dopamine, thus, positive effects are seen in stress-related cases. Blood circulation is regulated with breathing exercises, posture is kept in balance, and muscle density is maximized. Yoga, which teaches one to minimize physical fatigue encountered during the performance phase, helps control mental and physical stress with exercises done before the performance.

Finally, the study reviews the following aspects of left-hand anatomy and the appropriate techniques and exercises for the challenging cello passages in Tchaikovsky's afore mentioned works: the left-hand pattern, articulation, and agility. The "left-hand pattern" is the type of grip that allows successive notes or figures in similar intervals to be played with the same finger number. In order for the notes to be heard fluently and equally, it is necessary to maintain a right angle by providing hand and elbow coordination in the direction required by the position. In the left-hand pattern, the position change is made by moving the fingers from one point to another. "Articulation" is the process of pressing the fingers upwards, and "agility" is the state of being strong in terms of nimbleness, speed, and reflexes in the fingers. After discussing left-hand anatomy and suggestions for strengthening the left-hand fingers for agility and articulation, the exercises specifically designed for the difficult passages in Tchaikovsky's Manfred and Symphony No. 4 are illustrated. Examples of notes to practice with various variations to develop the left-hand pattern, position transitions, agility, and articulation are also provided. 


\section{Giriş}

Çalgı eğitiminde doğru bir teknikle ilerlemek için kişinin öncelikle fiziksel ve zihinsel farkındalı̆̆ını keşfedip özümsemesi ve bu farkındalığı icra aşamasında kullanabilme yetisine sahip olması gerekmektedir. İcra aşamasında, yanlış oturmuş bir teknikle beraber, vücudunu fiziksel olarak zorlamanın sonucunda kişi, sakatlanmalara yol açan patolojik icra alışkanlıkları geliştirebilir. Teknik açıdan yeteri kadar ilerleyemeyen icracı sadece bireysel enstrüman çalışmalarında değil, orkestra ve oda müziği gibi çalgı topluluklarında karşısına çıkacak olan zorlu pasajlarda da problemler yaşamaya başlar. Çalgı çalmak dokunsal, işitsel, görsel koordinasyon gerektiren güç ve karmaşık bir işlemdir. Bu karmaşık işlem, bir yandan icra yapılırken aynı anda icranın değerlendirilmesi, o sırada oluşan iyi veya kötü işitsel, dokunsal ve görsel uyaranların algılanarak anında düzeltilmesini gerektirir. İcra sırasında oluşan herhangi bir hata bazen icracının duygu durumunu da etkilediği için bu, duygusal gerginliğe, kaygıya ve kasların gerilimine sebep olabilir. O nedenle çalgı çalmayı öğretecek öğretmenin, öğrenmeye istekli ve yetenekli bir öğrenciyi bu tür karmaşı ve koordinasyon gerektiren icra esnasında iyi düzenlenmiş bir eğitim programını uygulaması önem taşımaktadır (Çilden, 2003, s. 298).

İcra aşamasından önce, gerekli 1sınma hareketlerini uygulayarak, doğru bir çalışma sürecine geçiş sağlanmalıdır. Vücudu sadece fiziksel anlamda hazırlamanın dışında, zihinsel anlamda da hazırlamak gerekmektedir. Beyinde olumsuz düşünceler barındırmak, icra aşamasında, başarı sağlamaya engel oluşturur. Gün içinde dikkat dağıtan ve odaklanmaya engel olan hareketlilik ve diğer yorucu günlük faaliyetler, bazen bu tür zihinsel ve fiziksel hazırlık egzersizlerine zaman ve ortam açısından olanak vermemektedir. Çalışma öncesi yapılan bedensel egzersizler ve isınma hareketleri önem arz eder. Bunun yanı sıra enstrüman çalınmadı ̆̆ı zamanlarda da tüm bedenin çalma pozisyonundaki haliyle oturma şekli göz önüne alınarak duruş ve hareket egzersizleri uygulanabilir. $\mathrm{Bu}$ şekilde, gün içinde başka işlerle ilgilenirken de enstrümanı tutuş ve oturuş formları ile parmakları ısıtmaya yönelik egzersizler bütünsel olarak da icracının tüm yaşantısına entegre edilmiş olur. İcra öncesi yapılan bu fiziksel ve zihinsel hazırlık ile, çalma aşamasında ve ileride yaşanabilecek olası fiziksel problemlerin önüne geçilmiş olur. Bursal'ın belirttiği gibi “[...] genç yaşta başlayan viyolonsel eğitiminde, icra kaygıları ile vücudun fiziksel sınırlılıklarının bilincine varmamış çalıcılar ve eğitimciler fizyolojik rahatsızlıklarla karşılaşabilmektedir. Bu durum meslek yaşantısı boyunca vücutta kalıcı olacak sakatlıklara sebep olabilir" (2019, s. 11). O nedenle de ileriki zamanlarda daha ciddi fiziksel sorunlarla karşılaşılmaması adına, müzik eğitimcilerinin öğrencilerine sadece 
enstrüman çalma açısından değil bütünsel olarak tüm bedenlerini bu eyleme hazırlama ve egzersiz çalışmalarına entegre etmeyi öğretmeleri yerinde olacaktır. Bu eğitim programları arasında en bilinenleri Alexander tekniği ve Feldenkrais metodudur.

\section{Yöntem}

Bu makale, Tchaikovsky'nin Manfred ve 4. Senfonileri'nin viyolonsel partisinde görülen ve teknik açıdan zorlayıcı pasajlarla sınılıdır, icracıların karşılaştı̆ı̆ güçlükler göz önüne alınarak, ne tür tekniklerle ve egzersizlerle bunların üstesinden gelebileceklerine dair öneriler içermektedir. Bu çalışmanın amacı, ilgili eserlerdeki viyolonsel partisinde ajilite ve artikülasyon problemleri yaşayanlar için sol el parmaklarını güçlendirmeye yönelik egzersiz önerileri ve çözümler sunmaktır. Fizik terapi yöntemlerinden Alexander tekniği ve Feldenkrais metodundan yararlanılarak beyin ile vücut koordinasyonun önemi değerlendirilmiştir. Stres ve gerginliği kontrol altında tutmayı sağlayan yoga ve meditasyonun yararlarından, ayrıca zihinsel farkındalık geliştirmenin öneminden bahsedilmiştir. Tchaikovsky'nin sözü edilen eserlerindeki teknik olarak zorlu viyolonsel pasajları için yazar tarafından teknik egzersizler tasarlanıp sunulmuştur.

\section{İcra Öncesi Yapılabilecek Egzersiz Metotları: Alexander Tekniği}

Alexander tekniğini kısaca açıklamak gerekirse, bu teknik “[...] zaman içinde fark edilmeden alışkanlık haline getirilmiş birçok hareketin engellenerek vücutta oluşan gerginlikleri rahatlatmaya yardımcı olan bir yeniden öğrenim metodudur. Bu teknik Avustralyalı aktör Frederick Matthias Alexander'ın (1869-1955) sahnede sesinin kısılması ve doktorların buna çare bulamaması sonucunda girdiği uzun soluklu bir kendini izleme döneminden sonra ortaya çıkmıştır” (Tezişçi Özmenay, 2018, s. 2). Bu teknikte öğretmen, öğrencinin vücudundaki kasılmış noktaları bularak, sağlıklı ve dengeli kas grubunun nasıl doğru kullanılması gerektiğini öğretir.

Alexander tekniği doğru duruş, sağlıklı nefes alabilme ve beyin ile vücudun koordinasyonunun sağlanması açısından çalgı çalanlar için çok değerli bir tekniktir. Bu tekniği kullanan bir çellist, doğru bir duruş ile çalışmalarında fiziksel rahatlama yaşadığı için veriminin arttığını fark eder ve çalışma motivasyonu da buna paralel olarak artar. F.M. Alexander'ın tekniğinde kullandığı bir terim olan 'bedensel zekâ' (kinestetik duyu), kaslar ve eklemlerde olan hareketleri beyine mesaj olarak gönderir. Çalgı icrası sırasında bedensel zekâsını kullanabilen kişi, beden kontrolünü sağlayarak olası hatalara yenik düşmez. 
Alexander tekniği, kişinin daha önceden yanlış oturmuş olan öğrenimlerini, doğal duruş üzerine kurulu zihinsel ve fiziksel egzersiz teknikleriyle düzeltmeye yardımcı olur. Sağlıksız nefes alışıla beraber yanlış oturuş pozisyonu, özellikle sirt ve omuzlarda uzun soluklu kronik ağrılara neden olmaktadır. Vücut yanlış pozisyonda oturmaya alışınca, doğru bir duruşta devamlılık sağlamak zorlaşır. Bu nedenle, icra esnasında beyin ile bedenin koordinasyonunda yaşanan problemler sonucu hızlı ve hareketli pasajlarda gereken aktif başarı sağlanamamış olur. Alexander tekniğinde doğru nefes kontrolünü kullanmayı öğrenen kişi, icra sırasındaki akışı sağlıklı bir şekilde tamamlar. Bu tekniğin ilk aşaması 'engelleme', ikinci aşaması 'bilinçli projeksiyon' (yönerge), üçüncüsü ise 'birincil kontrol'dür.

Alexander, gereksiz yere efor sarf etme durumunu kontrol edebilmek için 'engelleme' adını verdiği, özünde refleks olarak yapılan ve alışkanlıkları durdurabilme yetisini, bu teknik için kullanmıştır. Burada önemli olan, süreç içerisinde konsantrasyonu sağlayarak, hedef noktaya ulaşmaktan ziyade geçiş sırasındaki doğru noktalara odaklanmaktır. İcracı, bu yöntem ile zorlandığı pasajlarda, lüzumsuz efor sarf etmek yerine, gereksiz kasılmaları fark ederek, durabilme yetisini kullanır ve dikkat etmesi gereken noktalarda konsantrasyonunu yoğunlaştırarak vücudunu kontrol etmeyi öğrenir. Alexander tekniğinde 'bilinçli projeksiyon' ise bedeni doğru bir şekilde yönlendirebilmektir (Tezişçi Özmenay, 2018, s. 8). Güç kullanımını, uzuvların nasıl hareket etmesi gerektiği yetisini öğrenerek uygulanır.

'Birincil kontrol', baş, boyun ve sirt ilişkisini düzene sokma ilkesidir. Boyun, baş ve sırt arasında köprü görevi görür. Boyun kasları ne çok gergin ne de çok gevşek olmalıdır. $\mathrm{Bu}$ kaslar doğru kullanılmadığında, dengeli bir baş pozisyonu sağlanamaz ve boyun tutulması, baş ağrısı gibi fiziksel rahatsızlıklara neden olur. Baş ise serbest olmalı, öne ya da geriye doğru durmamalıdır. Başın omurga ile olan dengesi, sağlıklı bir duruşa olanak verir. Sirt ise yukarı uzamalı ve genişlemelidir (Tezişçi Özmenay, 2018, s. 7). Böylelikle rahat nefes alımı ve omuzların sırt ile dengelenmesiyle beraber sağlıklı bir duruş sağlanmış olur.

\section{Alexander Tekniğinde Solunum}

İcra aşamasında en dikkat edilmesi gereken unsurlardan biri de solunumdur. Nefes kontrolü doğru yönlendirilmediği zaman, nefes akışı sağlıklı bir şekilde tamamlanamaz. $\mathrm{Bu}$ nedenle de icra sırasında sıkışıklık hissi, stres ve odaklanma problemleri ortaya çıar. Alexander tekniğinde solunum için de yönergeler bulunmaktadır: "Odaklanmış durumda iken de nefes almaya devam etmek ve nefesin akmasına izin vermek, sıkışıp kalma his- 
sinden de kurtulmaya yardımcı olur” (Tezişçi Özmenay, 2018, s. 12). Bu tekniğin çıkış noktası Alexander'ın kendisidir: "Alexander, kendi üzerinde yararını gördükten kısa bir süre sonra çevresindekilere tüm göğüs kapasitesinin kullanıldığı derin nefes tekniğini öğretmeye başlamıştır” (Tezişçi Özmenay, 2018, s. 12). Bu teknikte kullanılan nefes egzersizleri ile icracı, yaşanabilecek bu tür problemlere çözüm olanağı sağlamış olacaktır. Alexander tekniği, genellikle lisanslı öğretmenler tarafından birebir uygulanır. Ders sırasında bir taraftan öğrenciye sözel bilgiler verilip yönlendirmeler yapılırken, diğer taraftan öğretmenin elleri öğrencinin üzerinde olacak şekilde çalışma yapılır. Öğretmenin ellerinin öğrencinin üzerinde olduğu çalışma yoluyla sağlanan beden ve zihin bağlantısı, Alexander tekniğine özel bir çalışma şeklidir ve bu tekniği diğer tekniklerden ayırır (Tezişci Özmenay, 2018, s. 9).

Bu teknikte kullanılan "[...] sandalye egzersizi, viyolonsel çalan kişiler için önemli bir egzersizdir. Bu egzersizle kişi, omurgaya binen ağırlığı eşit olarak bacaklara ve ayaklara yönlendirmeyi öğrenir, tüm yük belli bir noktada kalmadığı için de omurilik gereğinden fazla yorulmaz" (Gökalp, 2019, s. 39). Guildhall School'da viyolonsel alanında Alexander tekniği eğitimi veren Prof. Dr. Selma Gökçen, enstrüman üstünde çalışarak teknik beceriyi kazanmanın yerine, öncelikle tekniğin getirdiği prensipleri zihinsel olarak alg1lamanın önemine değinmiştir. Prensip olarak yerleşme süreci ise kişinin farkındalığını arttırarak verilen bilgileri doğru bir şekilde sentezlemesi sonucu oluşacaktır (Gökalp, 2019, s. 39).

Yanlış beden duruşu, icra aşamasında ve sonrasında fiziksel sorunlar yaşanmasına sebep olur. Viyolonsel çalan bir kişide en çok görülen duruş bozuklukları kamburluk, boyunu dengeli bir şekilde tutmamak, kasılma sonucu omuzları gereğinden fazla yukarıda tutmak, ağırlığı tek bir ayak üstüne vermek ve doğru nefes alma tekniğini uygulamamaktır. Pasajlarda yaşanılan gerginlik ve stres, parmakların akıcı bir şekilde ilerlemesine engel olur. Boyun, baş ve omurganın dengeli bir şekilde koordinasyon halinde olması, icra aşamasında kişinin yaşadığı fiziksel ve zihinsel problemleri ortadan kaldırır. Yukarıda açıklanan 'birincil kontrol' uygulaması vücuttaki gerginliği azaltır. Bu nedenle bu tekniğe yeni başlayanlar normalde kaslarının gergin olduğu anlarda daha iyi performans gösterdiklerini düşündüklerinden ve ilk zamanlarda bu gerilimi hissetmediklerinden dolayı kaslardaki gerilimin az olduğunu düşünebilirler (Tezişçi Özmenay, 2018, s. 6). Oysaki buradaki en önemli husus, vücudu gerilimden uzak tutup, çalış esnasında akıcılığı devam ettirmenin farkındalığıdır. 


\section{Feldenkrais Metodu}

Feldenkrais metoduna adını veren Moshe Feldenkrais, bu metodu yaşadığı bir kaza sonrası ameliyat olmayı seçmek yerine, alternatif çözüm arayışına girmesi sonucu yaratmıştır (Dilekli, 2019, s. 22). Bu metod, vücudun hareket kısıtlamalarının yarattığı fiziksel ve ruhsal yorgunluğun yerine, unutulmuş olan doğal hareket pozisyonlarının tekrar vücuda entegre etmek için kullanılır.

Feldenkrais metodu, daha detaylı açıklamak gerekirse, “[...] fizik, biyomekanik, sinirbilim, nöromusküler sistem ve öğrenme yaklaşımı prensipleri üzerine inşa edilmiştir. Dikkati farkındalığın dışında kalmış olan bedenin bölümleri üzerine yoğunlaştıran hareket dizgileri yoluyla kendilik imajını genişletmek hedeflerinden biridir" (Dilekli, 2019, s. 22). Zihindeki olumsuzluklar, fiziksel olarak da etkisini gösterir ve belli bölgelerde kasılmalara neden olarak ağrılara dönüşür. Öncelikle beyindeki stresin yarattığı sıkışıklık hissini ortadan kaldırmak gerekir. Feldenkrais metodu, Alexander metodundaki gibi beden duruşu ve kas grubunun doğru kullanımına yönelik farkındalık yaratan egzersizler bütünüdür. Feldenkrais metodunda dersler iki bölüme ayrılmaktadır: 'hareket yoluyla farkındalık' (awareness through movement) ve 'işlevsel bütünsellik' (functional integration) (Dilekli, 2019, s. 23).

'Hareket yoluyla farkındalık' dersleri, grup çalışması şeklinde yapılır. Hareketleri kendi bedenine en uygun şekilde entegre ederek beyin ve bedenin koordineli çalışması farkındalığının algılanması sağlanır (Dilekli, 2019, s. 23). Zorluk derecesi orta seviyede olan bu dersler, gözler kapalı olacak şekilde oturarak ya da ayakta yapılır (Kar, 2012, s. 39).

'Hareket yoluyla farkındalık' dersleriyle beynin istemli hareket bölümünde değişikliğe neden olunarak beynin bu kısmına etki edilmesi amaçlanır. İçeride gelişen süreçlerin ancak dışarıdaki kaslarda neden oldukları değişimlerle fark edilebileceğini söyleyen Feldenkrais ve Beringer (2010), hareket temelinde yapılacak önemli değişikliklerle kas aygıtının değişeceğini ve böylelikle alışkanlıkların en önemli dayanakları olan kas dayanaklarını kaybedeceklerini ve değişmeye uygun hale geleceklerinin altını çizer (Dilekli, 2019, s. 24).

Feldenkrais metodunu Türkiye'ye getiren Hayri Uzel ve Lizet Bicerano'dur. Feldenkrais metodunun ana amacı bedenin ve zihnin entegrasyonu ile iyileşmeyi sağlamaktır. Bu çalışma, özünde hareketleri doğru biçimde yapmaktan ziyade, kendi bedenine en uygun 
şekilde entegre edebilme becerisine sahip olmayı öğretir. 'İşlevsel bütünsellik' çalışmaları ise birebir yapılan derslerdir. Bu çalışmada kişi, yavaş hareketlerle yaptığı egzersizlerle, bedenini tanıyarak hareket farkındalığını öğrenir. Dersler ayakta durarak, yürüyerek, dizüstü ya da yere uzanarak gerçekleştirilir. Hareket aralarındaki dinlenme süreci çok önemlidir. Bu kısa molalar, o esnada vücutta yaşanılan değişikliklerin özümsenip farkındalığa dönüşmesine olanak sağlar.

Feldenkrais metodu, bireye, vücut farkındalığını öğreterek, duruş ve kas gruplarının dengeli bir şekilde koordinasyon halinde olmasını sağlar. Hareketler, kolay ve keyif alınabilecek egzersizlerden oluşmaktadır (Kar, 2012, s. 39). Kişinin yargılamalarda bulunarak düşüncelere dalmasının, onun net ve doğru olarak görmesini sağlayan farkındalık yeteneğini kesintiye uğrattığının altını çizen Feldenkrais (2010), 'hareket yoluyla farkındalık' derslerini bu tür bir kinestetik bilginin geliştirilmesi yönünde düzenlemiştir (Dilekli, 2019, s. 32).

Derslerin sonunda genellikle kişi hafif, uzamış hisseder (Dilekli, 2019, s. 25). Alexander ve Feldenkrais teknikleri, çalgıcının kendi vücudunu tanımasını ve istediği şekilde yönlendirmesini sağlayan egzersizlerden oluşmaktadır. Bu egzersizler ile kişi icra aşamasında vücudunu dengede tutarak olası zorlu pasajlarda nefes kontrolü, doğru bir duruş ve kaslarda oluşabilecek gerginliği en aza indirme kabiliyetini öğrenmiş olur.

\section{Performans Öncesinde ve Sırasında Uygulanabilecek Çeşitli Zihinsel Hazırlık Teknikleri}

Alexander tekniği ve Feldenkrais metodu, stres, kaygı bozukluğu ve teknik yetersizlik sonucu oluşabilecek kas gerginliği nedeniyle herhangi bir sakatlık yaşanmasını önlemek için kullanılabilecek yöntemlerdir. Bu tür fizik terapi teknikleri ve metotlardan bahsettikten sonra zihinsel hazırlık süreçlerine değinmek yerinde olacaktır.

\section{Bilişsel Yöntemler}

Çalg1 eğitimi konusunda bahsedilecek ilk eğilim, «bilişssel yöntemler〉dir. Teztel ve Aşkın'a göre “[...] bilişssel yöntemler, esas olarak kişide kaygı oluşturan ve ayrıca performans becerilerini etkileyen olumsuz düşünce sistemlerini değiştirmeye yönelik yöntemlerdir. Bunların ilki olan 'bilişsel yapılandırma,' kişinin düşüncelerini izleme, becerilerini etkileyen olumsuz fikirleri belirleme, bu düşüncelere zıt etkili ve yapıcı fikirler üretme, bu fikirler üzerinde yoğunlaşma ve bunları iş ile ilgili aktivitelere yönelt- 
me şeklinde uygulanır" (2007, s. 7). İcra aşamasında yaşanılan gerginliği önlemek için, kişinin icra öncesi problem yaşadığı noktaları tespit edip çözüm odaklı bir yaklaşım sergilemesi gerekmektedir.

\section{Ímgeleme Yöntemi}

"Zihinsel imgeleme, kişinin yaşayacağı, dolayısı ile zihnini arzu edilen performans tecrübesi ve sonucuna yönelik programlanması ile ilgilidir” (Teztel, 2007, s. 7). Kişi, icra öncesinde, çalacağı eseri gözünde canlandırarak görsel, ruhsal ve fiziksel olarak kendisini icraya hazırlamış olacaktır. Böylece akış süreci olumlu bir şekilde tamamlanacaktır. Zihinsel imgelemeyi kullanmayan kişi, tedirgin olduğu pasajlarda, vücut kaslarının normalden fazla gerilmesine yol açarak hata yapma olasılığını arttırır ve hatta sakatlanmalara neden olabilir. Özellikle ajilite gerektiren pasajların icrası öncesinde, beyinde kurgulama yöntemiyle hazırlık yapılması, beyinden gelen yönlendirme komutunun fiziksel olarak vücuda aktarılması sayesinde yaşanabilecek olumsuz durumlar önlenebilir. Zihinsel imgelemede 'davranış provası' önemli bir rol oynar:

Davranış ile ilgili yöntemler, kişide sahne heyecanı nedeniyle görülen olumsuz davranış şekillerini değiştirmeye yönelir. 'Davranış provası', icracının sık sık farklı ortamlarda çalarak, sahne tecrübesini esas konser zamanından önce birçok kez yaşamasına yönelik yapılan çalışmadır. Buradaki amaç, zihnin ve bedenin rahatlatılarak, stres yaratan olgulara karşı pozitif yaklaşım farkındalığını sağlamaktır. 'İlerlemeli gevşeme', belirli kas gruplarının sırayla kasılıp gevşetilerek yapıldı̆̆ı bir rahatlama yöntemidir. Bu yöntem, ayaklardan başlayıp sırayla vücudun yukarı doğru diğer bölümlerindeki değişik kas grupları derin nefesler eşliğinde ve belli bir sayı ile kasılıp gevşetilerek uygulanabilir (Teztel ve Aşkın, 2007, s. 8).

Konser öncesi meditasyon, yoga gibi yöntemlerle de kasları gevşeterek, odaklanmaya yönelik çalışmalar yapılabilir. Ayrıca nefes egzersizleriyle stresi önleyerek rahat ve akıcı bir performans sağlanabilir. "Belirli bir süre için bilincin bir odak noktası üzerinde kalabilmesi, oldukça büyük bir zihinsel disiplin ve emek gerektirir. Bu nedenle icracıların gündelik hayatlarında, odaklanmayı geliştiren ve tamamen o ana konsantre olmayı destekleyen meditasyon ve mindfulness gibi kavramları uygulamalarına sistemli olarak yer vermelerinde yarar olacaktır' (Teztel, 2007, s. 13). 'Mindfulness', son zamanlarda çok sık duyulan bir terim olarak, yaşanılan anı ve o anda etrafta gerçekleşenleri net ve olduğu 
gibi algılayıp fark etmek anlamında kullanılmaktadır. $\mathrm{Bu}$ farkındalık sırasında algılarını yeterince açıp zihinden geçen düşünceleri, vücudun hissettiklerini, kısacası çevremizde ve kendi bedenimizde gerçekleşenlerin farkında olarak yargılamadan anda kalabilme durumudur. Performans becerilerini etkileyen bilişsel yöntemler, zihinsel imgeleme ve davranış provaları ile 'anda kalabilme' durumuyla gerçekleşen 'farkındalık' hali, icra sırasında müzisyenin bedeni ve icra ettiği müzik arasında bağlantı kurmasına ve başarı sağlamasına yardımcı olmaktadır.

\section{Yoga ve Meditasyonun Fiziksel ile Zihinsel Hazırlık Üzerindeki Olum- lu Etkileri}

Yoga, hem fiziksel olarak kasların 1sınması, esneklik, kasları gevşetme ve kuvvetlendirme, vücudun hareketlerine konsantre olma, denge hareketleri ile, hem de uygulanan hareketler sırasındaki düzenli ve derin nefes alış-verişlerin buna eşlik etmesi sebebiyle müzik eğitiminde iyi bir hazırlık öğretisidir. Fiziksel açıdan kas yoğunluğunu geliştiren, ruhsal açıdan da odaklanma, stres ve kaygıyı azaltmaya yönelik egzersizleriyle müzisyenler için çok yararlı bir uygulama olan yoga, kişinin ruhsal ve bedensel açıdan içsel farkındalığını keşfetmesine, zihinsel ve fiziksel olumsuzluklara karşı kendini koruyabilme yetisine sahip olmasına yardımcı olur. Yoga yapan bir kişi ruhsal ve bedensel açıdan içsel farkındalığını keşfederek, zihinsel ve fiziksel olumsuzluklara karşı kendini koruyabilme yetisine sahip olur. Yoga, kan dolaşımını hızlandırır ve vücuttaki oksijeni hücrelere taşıyarak dolaşımın daha sağlıklı olmasını sağlar, bu sayede beyin daha kaliteli oksijen alarak dikkat yoğunluğunu arttırır. Yoga yapan kişi bu egzersizler sayesinde duruş pozisyonunu dengede tutarak kas yoğunluğunu en üst seviyeye taşır ve icra aşamasında karşılaşılacak fiziksel yorgunluğu en aza indirgemeyi öğrenir.

Yoga yaparken vücut serotonin ve dopamin salgilar; bu sayede strese bağlı olgularda pozitif etkiler görülür. Nefes egzersizleri ile kan dolaşımını düzenler, duruş pozisyonunu dengede tutarak kas yoğunluğunu en üst seviyeye taşır. İcra aşamasında karşılaşılacak fiziksel yorgunluğu en aza indirgemeyi öğreten yoga, icra öncesi yapılan egzersizlerle de zihinsel ve bedensel stresi kontrol etmeye yardımcı olur.

Yoganın psikolojik etkileri konusunda yapılan araştırmalarda stres ve depresyonu azalttı̆̆ de önemli rol oynadığ 1 görülmüştür. (Simard ve Henry, 2009, s. 950-952; Schultz, Uyterhoeven ve Khalsa, 2011, s. 103; Stueck ve Gloeckner, 2005, s. 371-377). Öte yandan 
yapılan başka araştırmalara göre (Davidson, Kabat-Zinn, Schumacher, Rosenkranz, Muller, Santorelli ve Sheridan, 2003, s. 564-570) konsantrasyon, bireyin bedenine anlık odaklanması ve bağlantı kurmasını sağlayan bir beceridir. Khalsa ve Gould'un (2012) araştırmasında deneye katılanlar üzerinde yapılan gözleme göre yoga ve meditasyon uygulamalarının stresle başa çıkma, hafızayı güçlendirme, konsantrasyon ve anlama kabiliyetini geliştirme gibi olumlu sonuçlar verdiği görülmüştür.

Meditasyon, derin düşünce anlamında kullanılan bir terim olarak yoga ile özdeşleştirilmiştir. Ünlü düşünür Osho, meditasyon hakkında şu görüşünü dile getirir: "[...] meditasyon, özünde bireyin içinde ve çevresinde olup bitenlerin farkında olma sanatıdır. En iyi halimize kavuşabilmek, her anımıza en iyi halimizi vermek ve her andan en iyiyi elde etmek için mümkün olduğunca farkında olmamız gerektiğini anlamaktır. Farkında olmak içinse, gevşememiz gerekmektedir” (2011, s. 11-12).

Meditasyonun gerçekleşebilmesi için temel koşullar şunlardır: kişi, öncelikle rahat, dik, tabanlar yere basıll, eller ve ayaklar bağlanmadan iki yanda olacak şekilde, elden geldiğince dengeli bir oturma biçiminde olmalıdır. Ruhsal ve fiziksel dinginlik sağlamak için, ses, hareket ve 1şık gibi rahatsız edebilecek ortamlardan uzak bir yerde konsantre olacağımız nesne -yani bedene ve enstrümana- odaklanmalıdır (Dexter, 1996, s. 33). Odaklanmada düzenli ve heyecansız bir solunum önemli bir rol oynar. Özellikle yoga tekniğinde kullanılan Pranayama nefes tekniği, nefes kontrolü için uygulanabilir (Kartal, 2016, s. 105). Rahat bir duruşta dik bir pozisyonda oturulur. Sağ elin işaret ve yüzük parmakları alına konulur. Baş parmak ile sağ burun deliği kapatılır ve diğer burun deliğinden sakince nefes verilir. Yine sol burun deliğinden aynı şekilde sakince ve derince nefes alınır. Nefesi boşalttığımızda kaburgalara dayanan diyafram kasının nefes alma sırasında gevşeyerek aşağıya doğru itilmesi sağlanır. Bu şekilde kaburgaların iki uç kısmı yanlara doğru genişleyerek akciğerlerin kapasitesi arttırılır. Sonra yüzük parmağıyla sol burun deliği kapatılır ve sağ burun deliğinden sakince nefesi verilir. Sağ burun deliğinden tekrar sakince nefes alınır. Bu dönüşümlü nefes alıp-verme işlemine en az 3 dakika devam edilir (Kartal, 2016, s. 105).

Yoga sırasındaki nefes ve beden esnekliğinin yanı sıra düşüncelerde odaklanma halini kolaylaştıran bir faaliyettir. Meditasyon iç huzurun farkındalığını kavrama, doğru nefes tekniğini kullanabilme ve vücudunu tanımaya olanak sağlayan deneyimlerin bütünüdür. Bir bakıma kişinin kendi içinde huzur bulduğu durumdur. Derin düşünme hali ve derin 
nefes alıp-verme egzersizleri ile kan basıncı düşer, nabız yavaşlar ve kaygı durumu azalır. Bu çalışmayla, icra sırasında konsantrasyona hazırlık sağlanmış olur. Performans s1rasında yaşanılan kaygı ve stresin en büyük nedeni düşünce sistemimizdir.

\section{Sol El Anatomisi}

El mekanizmasının önemli bir unsuru olan kas, üzerine yapıştığı kemik dokuların hareketini sağlayan, kasılabilme özelliğine sahip hareketin aktif organlarıdır (Bingöl, $2021 \mathrm{~s}$. 2). Üç tip kas vardır: çizgili (iskelet) kaslar, düz kaslar ve kalp kası (miyokard). Kasların uyarılmasını beyin ve omurilik sağlar (Ak Güven, 2020, s. 3).

Nuzumlalı'ya göre tendonlar ve kaslar birlikte çalışırlar. Genel anlamıyla parmakların bükülmesini ve açılmasını sağlayan sistem tendonlardır. Tendonların adaleleri (kasları) ön kol seviyesindedir. Bu kaslar bilek seviyesine gelerek tendon dediğimiz kıkırdağımsı yapıları oluşturur ve parmaklara ulaşarak parmakların bükülmesini sağlarlar. Her parmağın bükülmesinde farklı tendonlar rol oynar. Bu görev, tek bir tendonun işi değil, birkaç tendonun görevidir. Burada önemli olan husus, bükme sırasında, bükücü kaslar çalışırken kaldırıcı olanların gevşemesidir (kişisel iletişim, 25 Eylül 2020). ${ }^{1}$

El bileğini büken ve kaldıranlarla, parmakları büken (fleksör) ve kaldıranlar farklı tendonlardır. Ön koldan gelen adale (tendon) bilek kısmında dörde ayrılır; yani dört tendon oluşur. Bu tendonlar 4 parmağa gider ve kaldırılmalarını sağlar. Bu adaleler ortak olduğu için birlikte hareket etmek durumundadırlar. Bu tendonların dışında çok hassas fonksiyonlar yapabilmesi için işaret parmağı ile serçe parmağına ait 2 tane adale tendon grubu vardır. Bu nedenle işaret parmağı ile serçe parmak bağımsız olarak ayrı ayrı kalkar (kişisel iletişim, 25 Eylül 2020). İcra aşamasında, serilik gereken pasajlarda, sol el 3. ve 4. parmaklarda teknik açıdan fiziksel olarak zorlanma görülmektedir. Bunun nedeni bu parmakların kendilerine ait tendonlarının olmaması ve bağımsız hareket edememeleridir. Bu parmakların tendonları ortak olduğu için her iki parmağı kaldırmaya çalıştığınızda (ekstansor) diğerleri de kalkmaya çalışır. Diğer bir deyişle bu birbirinden bağımsız hareket edememe durumu parmakların güçsüzlüğünden değil, anatomik olarak birbiriyle bağlantılı olmaları ve tek bașına hareket edememelerinden kaynaklanmaktadır. Burada

1 Doç. Dr. Ersin Nuzumlalı, Ortopedi ve Travmatoloji, El Cerrahisi ve Mikrocerrahi Uzmanı. İstanbul El Cerrahisi ve Mikrocerrahi Merkezi'nde görev yapmaktadır ve bu iki paragraftaki bilgiler, 25 Eylül 2020'de gerçekleştirilen mülakat sonucu elde edilmiş olup bu bilgilerin yayımlanması konusunda KVKK çerçevesinde kendisinden izin alınmıştır. 
önemli olan yüzük parmağını güçlendirmekten ziyade öncelikli olarak beyin-adale uyumunun sağlanması ile koordinasyonu yükseltmektir. Öncelikle görsel olarak parmağı takip ederek bağımsız kullanabilme becerisini arttırmaya yönelik egzersizler yapılabilir. Beyin bu hareketi görsel olarak hafizasına aldıktan sonra parmak, beyinden gelen doğru mesajla hareketi tamamlayacaktır (kişisel iletişim, 25 Eylül 2020).

\section{Viyolonselde Sol Elin Tuş Üstünde Konumlandırılması}

Sol el kalıbı düşünüldüğünde art arda gelen notaların ya da benzer aralıktaki figürlerin aynı parmak numarası ile çalınmasını sağlayan tutuş şeklidir. Notaların akıcı ve eşit bir şekilde duyulması için pozisyonun gerektirdiği yönde el ve dirsek koordinasyonu sağlanarak doğru açının korunması gerekmektedir. Ajilite gerektiren pasajlarda parmakları tek tek çalmayı düşünmek yerine pozisyon kalıbını düşünerek çalmak, hata yapma olasılığını ve hantallaşmayı engelleyecektir.

Pozisyon değiştirme esnasında sol el kalıbında parmakların bir noktadan başka bir noktaya gitmesi ile pozisyon değişimi yapılır. Pozisyon geçişlerinde öncelikle parmak kalıbı korunmalı, doğru duatelerle parmak takibi yapılmalıdır. Pozisyon değişimlerinde parmaklar esnek tutulmalı ve kasılmamalıdır (Bursal, 2019, s. 26).

Artikülasyon, parmakların yukarıya kaldırılarak basılması işlemidir. Ajilite gerektiren pasajlarda gereğinden fazla yapılan artikülasyon sonucunda parmaklar çabuk yorulur ve notalar arasında boşluk kaldığı için istenilen hıza ulaşım sağlanamaz. Bunu önlemek için öncelikle artikülasyon çalışmaları ile parmaklar arasındaki kuvvet eşitliğini dengelemek gerekir (Bursal, 2019, s. 37). Ajilite parmaklarda çeviklik, hız ve refleks yönünden kuvvetli olma durumudur. Ajilite için öncelikle pozisyon geçişlerine hâkim olmak, doğru duate seçimi yapabilmek ve parmakları pozisyonun gerektirdiği şekilde eşit artikülasyon ile basarak çalınabilmesi gerekmektedir (Bursal, 2019, s. 10).

\section{Sol El Parmaklarının Ajilite ve Artikülasyon Konusunda Kuvvetlen- dirilmesine Yönelik Öneriler}

Çalg1 eğitiminin en önemli temel kurallarından biri, beden koordinasyonunu sağlamaktır. Bunun için öncelikle bilgiyi doğru bir şekilde özümseyerek vücuda aktarmak gerekmektedir. İcra aşamasında beyinden gelen yanlış bilgilendirmeler sonucunda hata riski ortaya çıkmaktadır. Özellikle serilik gerektiren pasajlarda bu hata riski çok daha yüksektir. Zihinsel olarak hazır olmayan vücut, fiziksel olarak da hazır olamamaktadır. Bu du- 
rumu önlemek için öncelikle pasaj analizi, pozisyon geçişlerinde doğru parmak kalıplarının kullanımı, kasları sıkmadan akışı tamamlama yetisini öğrenmek gerekmektedir. $\mathrm{Bu}$ tür pasajlarda yaşanılan problemlerden biri de gereğinden fazla yapılan artikülasyon sonucu istenilen hızda devamlılık sağlayamamaktır. Parmakları tek tek çalmayı düşünmekten ziyade kalıp olarak düşünerek istenilen hıza ulaşım sağlanmalıdır. Kapalı pozisyonlarda parmaklar birbirine yakın tutulmalı ve eşit konuma getirilmelidir. Esneklik gerektiren açık pozisyonlarda ise parmakları sıkmadan hafif çalmayı düşünerek pasaj tamamlanmalıdır.

\section{Egzersizler}

Tchaikovsky’nin 4. ve Manfred Senfonileri’ndeki zor pasajlar için çalışmalar aşağıda yer almaktadır. Sol el kalıbı, pozisyon geçişleri, ajilite ve artikülasyon geliştirmek için çeşitli varyasyonlarla çalışılacak nota örnekleri yazar tarafından hazırlanmıştır ve ilgili eserlerin notalarının altında açıklamalarıyla yer almaktadır.

\section{Tchaikovsky, Senfoni No. 4, Op. 36, 4. Bölüm Finale, Allegro con fuoco}

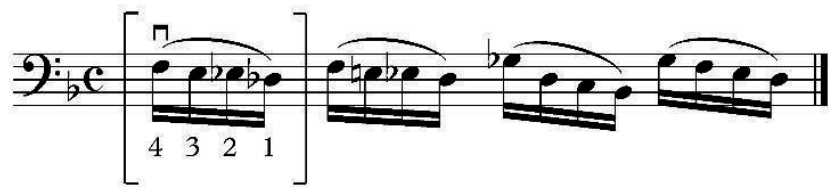

Örnek 1. Senfoni No. 4, Op. 36, Ölçü 84 (Tchaikovsky, 1960, s. 16).

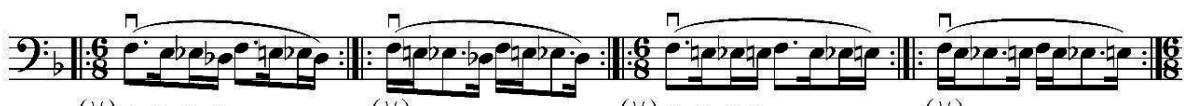

(V) $4 \quad 3 \quad 2 \quad 1$

(V)

(V) 4323

(

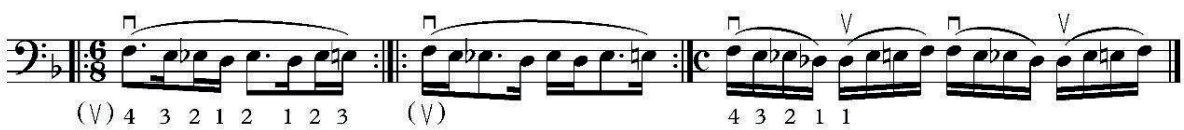

Örnek 1a. Senfoni No. 4, Op. 36, Ölçü 84, artikülasyon egzersizi (Ersoy, 2021). 
Yukarıda Örnek 1'de görüldüğ̈ü gibi art arda gelen, tekrarlayan kromatik pasaj inişlerinde, 3. ve 4. parmaklar belirli bir süre sonra artikülasyon açısından zorlanarak yorulmaya başlar ve kasılır. Bunun sonucunda da temiz bir entonasyonun sürdürülmesi ve sabit bir hızda devamlılığın sağlanması zorlaşır. Bu parmakları Örnek 1a'daki egzersizde olduğu gibi çıkıcı ve inici yönde çalıştırarak artikülasyon ve ajilite için parmaklar arasında eşit bir kuvvet sağlanabilecektir.

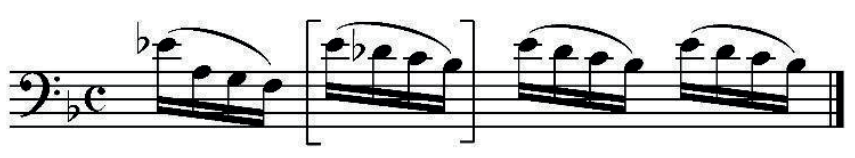

Örnek 2. Senfoni No. 4, Op. 36, Ölçü 85 (Tchaikovsky, 1960, s. 16).
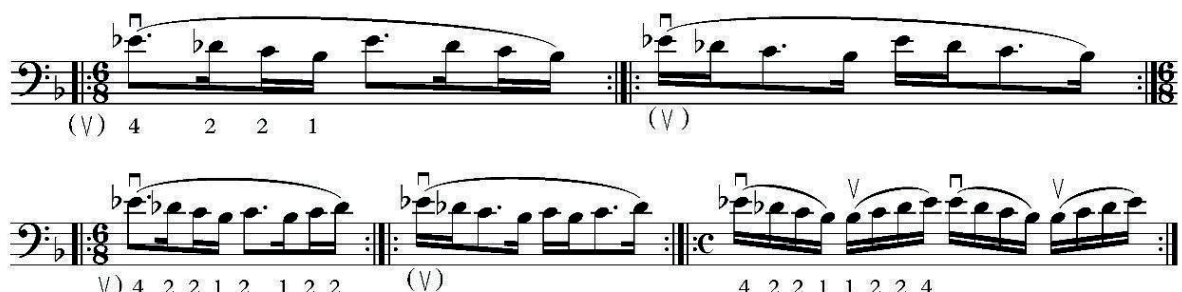

V) $42221212 \quad 122$

(V)

$\begin{array}{llllllllllll}4 & 2 & 2 & 1 & 1 & 2 & 2 & 4\end{array}$

Örnek 2a. Senfoni No. 4, Op. 36, Ölçü 85, artikülasyon egzersizi (Ersoy, 2021).

Yukarıdaki Örnek 2'deki pasajda, 2. parmağın, ardından gelen notada tekrar kullanımı, ajilite ve artikülasyon sırasında icracılara zorluk yaşatabilmektedir. Özellikle yapılan en büyük hata, tekrarlayan notalarda, ilk 2. parmak ile basılan notanın (Re bemol), diğer notaya (Do) geçişi sırasında uzun tutulmasının, glissando'ya neden olabilmesidir. Bunu önlemek için Örnek 2a'da yer alan örnekteki gibi, ilk nota, uzun düşünülmeden, 2. notaya parmak ile hafif bir vurgu vererek geçişi sağlamak, istemeden oluşan böyle bir glissando etkisini ve entonasyon sorununu ortadan kaldırmada yardımcı olacaktır.

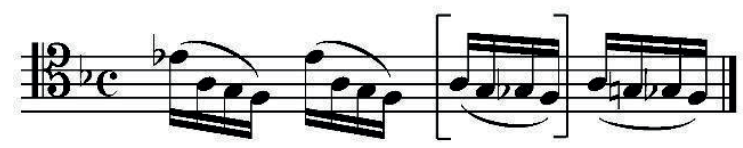

Örnek 3. Senfoni No. 4, Op. 36, Ölçü 88 (Tchaikovsky, 1960, s. 17). 

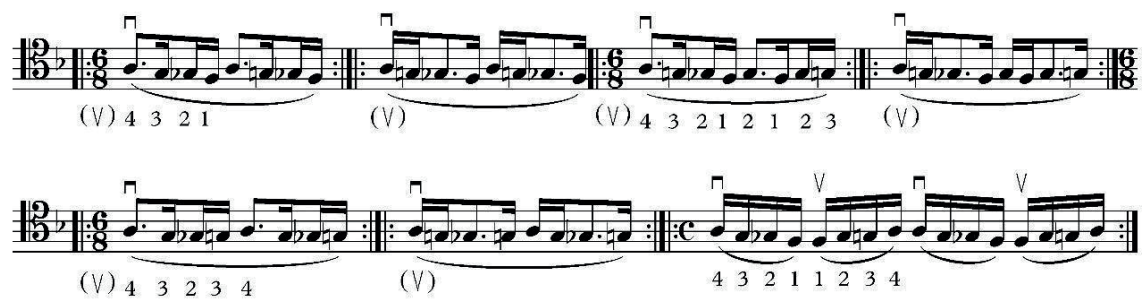

Örnek 3a. Senfoni No. 4, Op. 36, Ölçü 88, artikülasyon egzersizi, (Ersoy, 2021).

Yukarıdaki pasajda Örnek 3 'te görülen ve özellikle ilk 2 notada, 4. parmaktan sonra gelen 3. parmak kullanımı, icracılar için zorluk teşkil edebilmektedir. Bunun nedeni 3. ve 4. parmakların esneklik açısından yeterince kuvvetlendirilmemesidir. Örnek 3a'daki egzersiz, pasajın çıkıcı ve inici yönü açısından kuvvetlendirilmesine yardımcı olarak 3 . ve 4. parmakların esneklik kazanmasını sağlayacaktır.

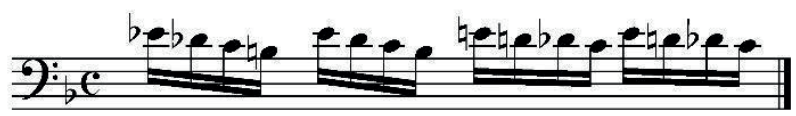

Örnek 4. Senfoni No. 4, Op. 36, Ölçü 275 (Tchaikovsky, 1960, s. 20).
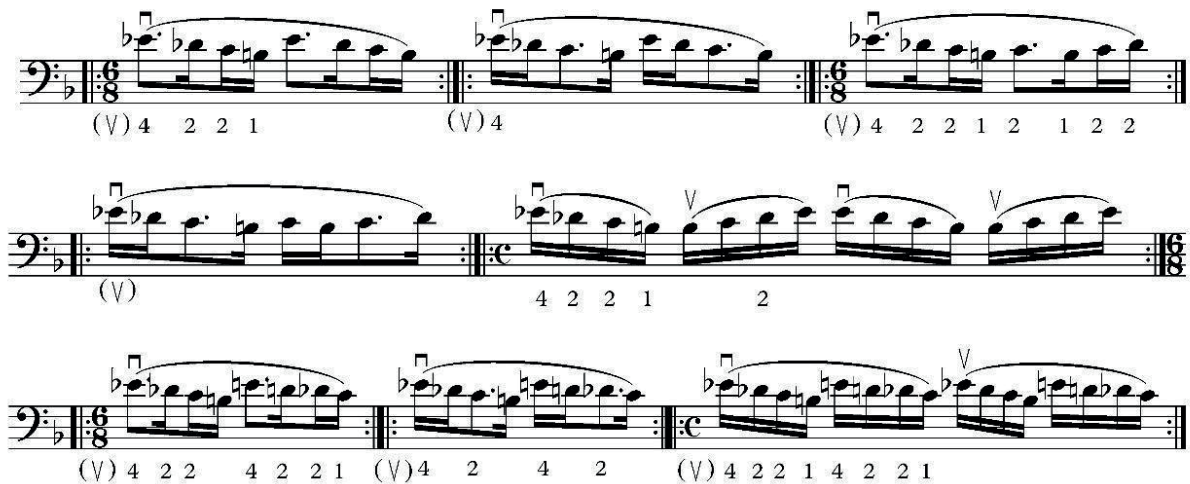

Örnek 4a. Senfoni No. 4, Op. 36, Ölçü 275, artikülasyon egzersizi (Ersoy, 2021).

Örnek 3'te yer alan örnektekine benzer bir pasaj olan ve Örnek 4'te görülen pasajda, 2. parmağın, Re bemol-Do üzerinde ardından gelen notada tekrar kullanımı, ajilite ve arti- 
külasyon sırasında icracılara zorluk yaşatabilmektedir. Bunu önlemek için ilk nota uzun düşünülmeden 2. notaya parmak ile hafif bir vurgu vererek parmak geçişi sağlanmış olacaktır (Örnek 4a).

\section{Tchaikovsky, Manfred Senfonisi, Op. 58, 1. Bölüm, Lento lugubre}

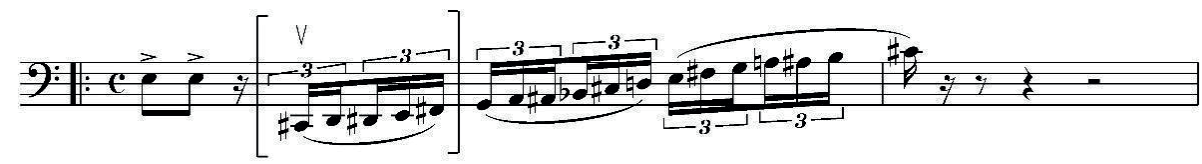

Örnek 5. Manfred Senfonisi, Op. 58, Ölçü 91 (Tchaikovsky, 1933-1970, s. 2).
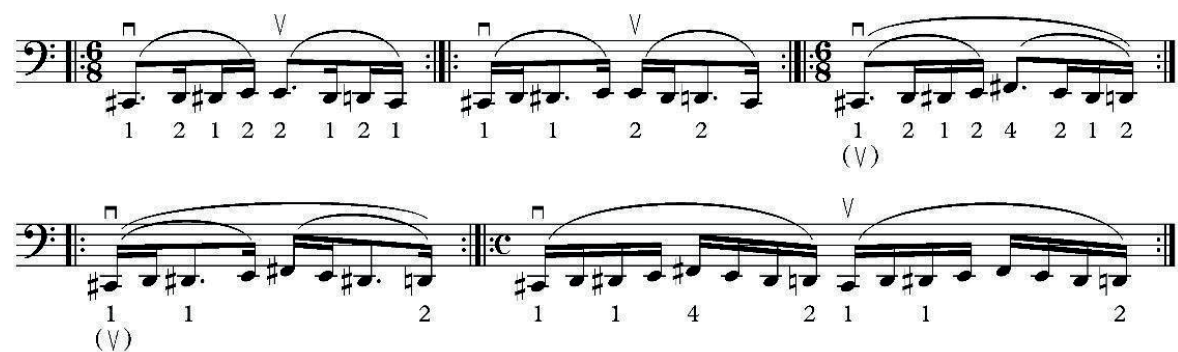

Örnek 5a. Manfred Senfonisi, Op. 58, Ölçü 91, artikülasyon egzersizi (Ersoy, 2021).

Örnek 5'te yer alan Do telindeki çıkıcı kromatik pasajda, art arda gelen 1. ve 2. parmakların artikülasyon ve ajilite yönünden çalıştırılmaması halinde, belirli bir tekrardan sonra bu durum icracılara el kasılması şeklinde bir sorun oluşturabilmektedir. Örnek 5a'da sunulan bu egzersiz ile parmakların çıkıcı ve inici yönündeki melodi yapısındaki pozisyon geçişleri kuvvetlenecektir.

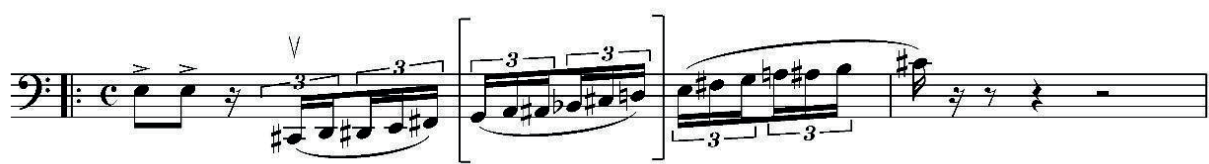

Örnek 6. Manfred Senfonisi, Op. 58, Ölçü 91 (Tchaikovsky, 1933-1970, s. 2). 

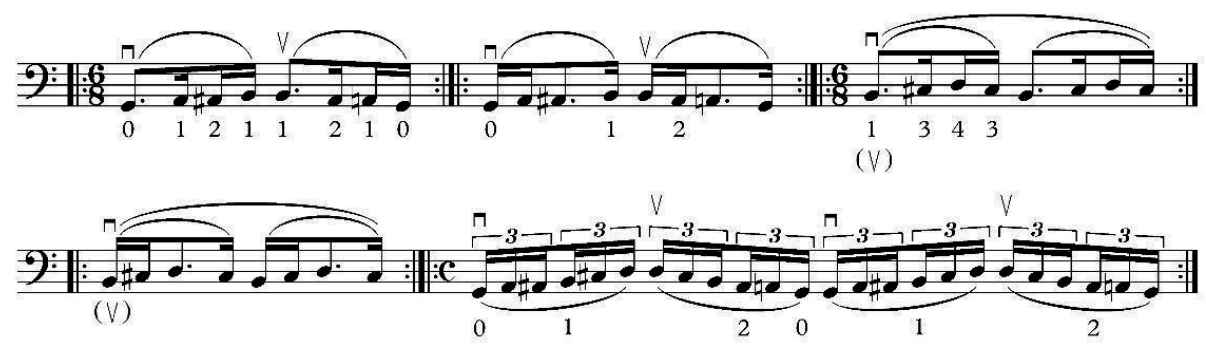

Örnek 6a. Manfred Senfonisi, Op. 58, Ölçü 91, artikülasyon egzersizi (Ersoy, 2021).

Örnek 6'daki Sol telindeki çıkıcı kromatik pasajında, 1. ve 2. parmağı kuvvetlendirmeye yönelik egzersiz önerileri Örnek 6a'da yer almaktadır. Son ölçüde bu pasaj, çıkıcı ve inici bir melodik yapıda tekrar edilir. Bu yöntemle pozisyon geçişleri ve artikülasyon açısından parmaklar kuvvetlendirilmiş olacaktır.

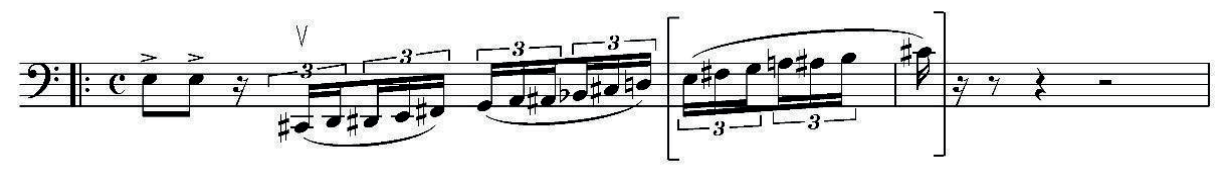

Örnek 7. Manfred Senfonisi, Op. 58, Ölçü 91 (Tchaikovsky, 1933-1970, s. 2).
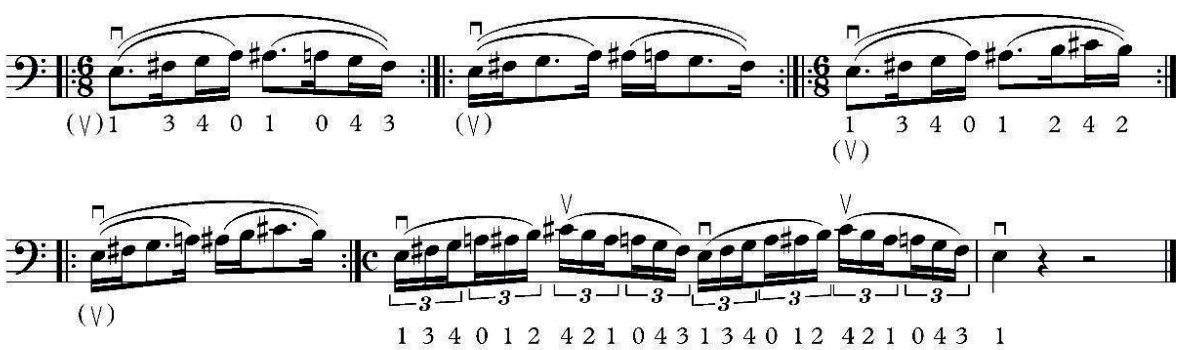

Örnek 7a. Manfred Senfonisi, Op. 58, Ölçü 91, artikülasyon egzersizi (Ersoy, 2021).

Örnek 7'de, Re telinde başlayan çıkıcı kromatik pasajda, sol el pozisyonunda parmakların birbirine yakın basılması gerekmektedir. Burada kapalı bir sol el pozisyonu düşünülerek, parmakların büyük artikülasyon hareketleri yerine birbirlerine eşit konumda tutularak daha küçük ve çevik hareketlerle basmak gerekmektedir (Örnek 7a). 


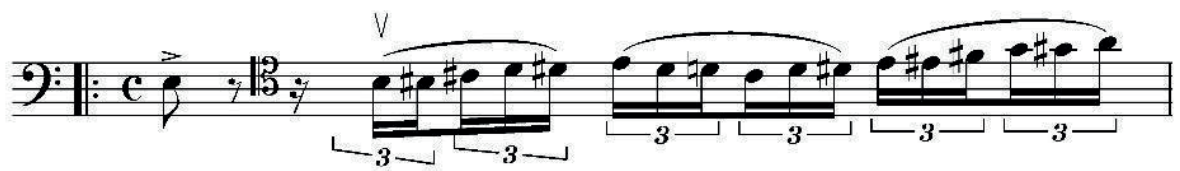

Örnek 8. Manfred Senfonisi Op. 58, Ölçü 1 (Tchaikovsky, 1933-1970, s. 2).
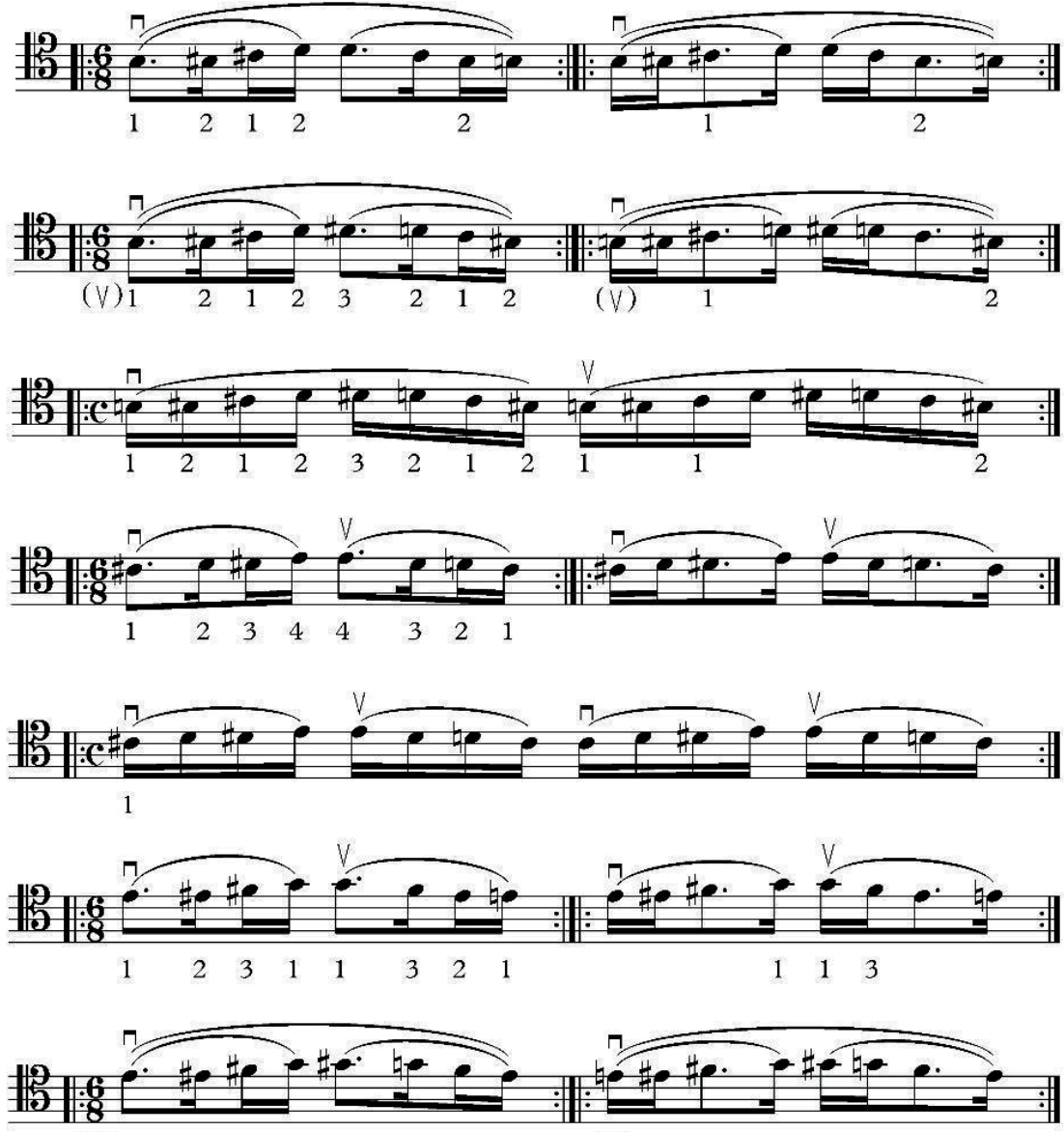

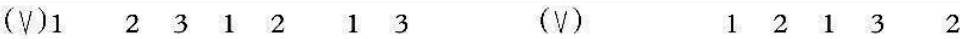

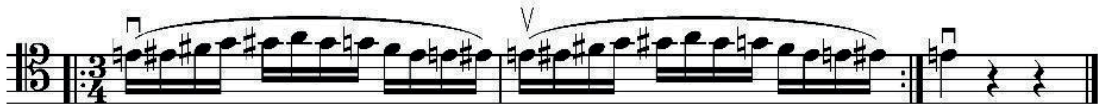

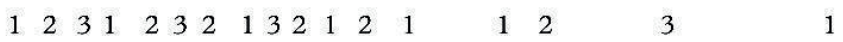

Örnek 8a. Manfred Senfonisi, Op. 58, Ölçü 95, artikülasyon egzersizi (Ersoy, 2021). 
Yukarıda görülen (Örnek 8) La telindeki bu çıkıcı kromatik pasajda, yine kapalı el pozisyonu düşünülmeli ve büyük artikülasyon hareketleri yerine parmaklar birbirlerine eşit konumda tutularak basılmalıdır (Örnek 8a).

\section{Tchaikovsky, Manfred Senfonisi, Op. 58, 2. Bölüm, Vivace con spirito}

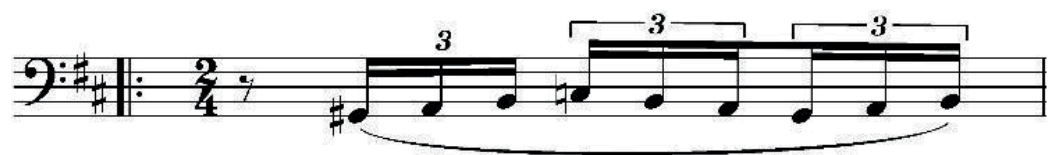

Örnek 9. Manfred Senfonisi Op. 58, Ölçü 39 (Tchaikovsky, 1933-1970, s. 6).
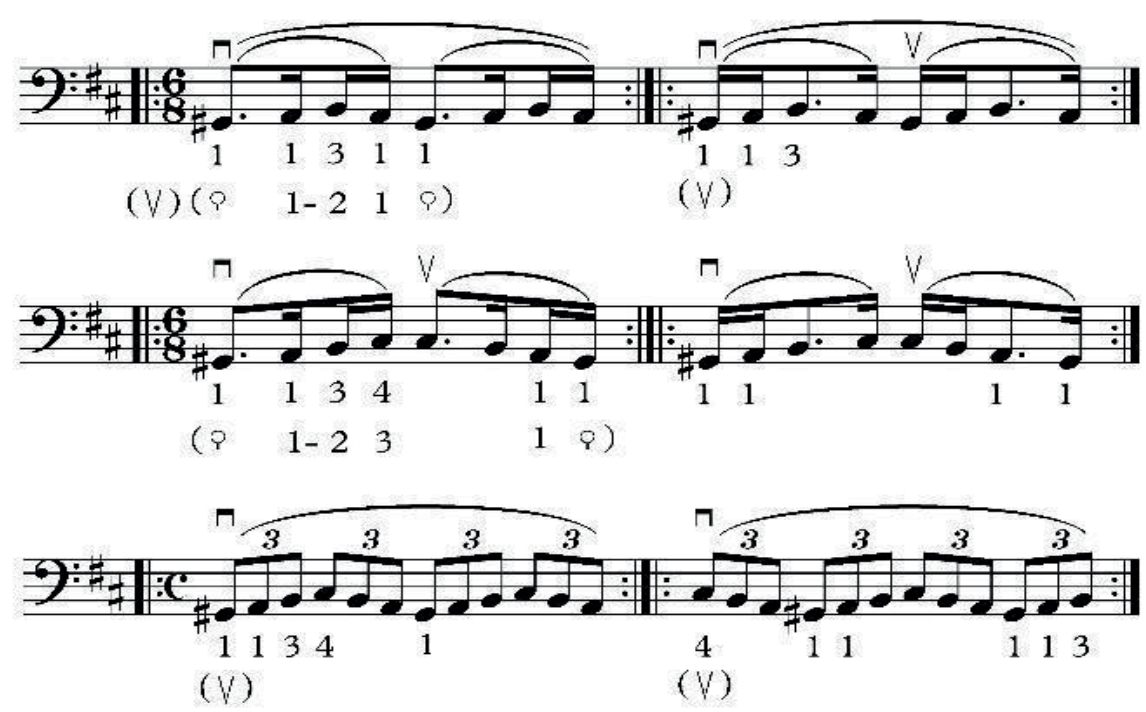

Örnek 9a. Manfred Senfonisi Op. 58, Ölçü 39, artikülasyon egzersizi (Ersoy, 2021).

Örnek 9'daki Sol telindeki bu pasajda, 2 ayrı duate örneği verilmiştir. İlk duate örneğinde, ilk 2 notada 1. parmak kullanılmıştır. Serilik gerektiren bir pasaj olduğu için 1. parmağın diğer notaya geçerken kuvvetli ve emin bir şekilde geçmesi gerekmektedir. Bu tür serilik gerektiren pasajlarda en önemli husus, ilk nota ve son notayı daha baskın hissederek basmaktır. Aradaki notaları tek tek düşünmek yerine pozisyonu düşünerek çalmak gerekmektedir. İkinci duate örneğinde ise pus kullanarak (baş parmak) gereğinden fazla parmakları hareket ettirmeden serilik sağlanabilecektir (Örnek 9a). 


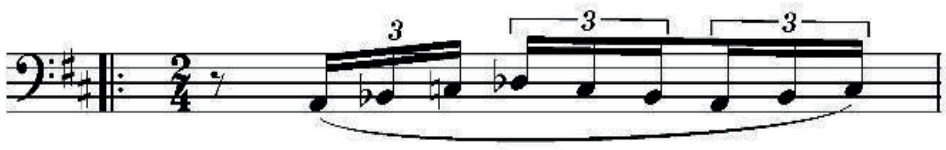

Örnek 10. Manfred Senfonisi Op. 58, Ölçü 59 (Tchaikovsky, 1933-1970, s. 6).
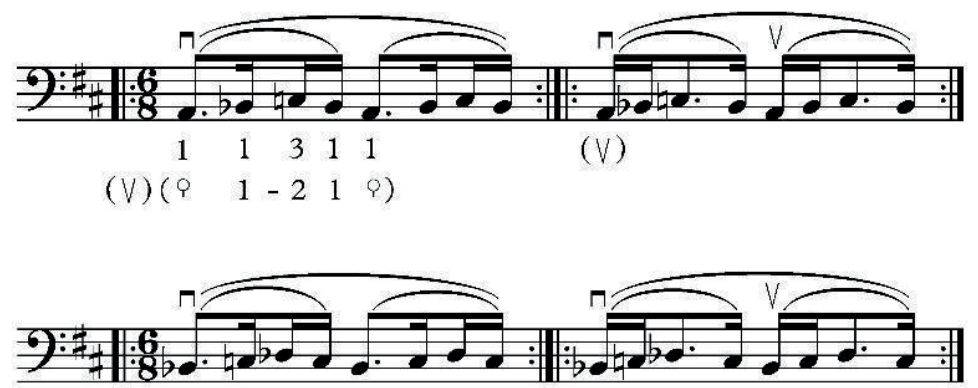

$\begin{array}{lllll}1 & 3 & 4 & 3 & 1\end{array}$

( $v)$

(V) $\left(\begin{array}{lllll}1 & -2 & 3 & 2 & 1\end{array}\right)$

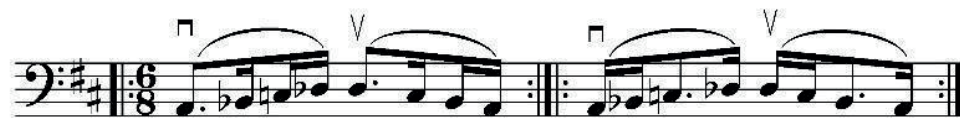

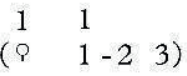

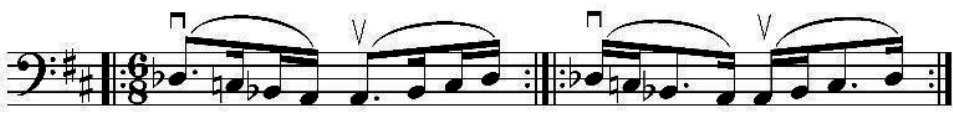

$\begin{array}{llllllll}4 & 3 & 1 & 1 & 1 & 3 & 4\end{array}$

(3 $2-1$ 9) (9 1-2 3)

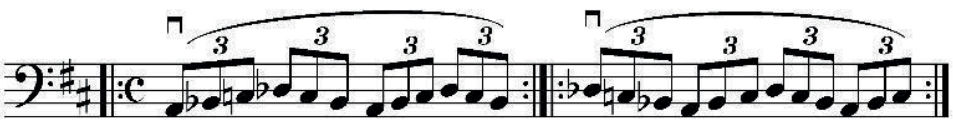
(V) $1 \begin{array}{lllllll}1 & 1 & 3 & 4 & 3 & 1 & 1\end{array}$
(9 1 - -2 (2 2-1)
(V) $4 \begin{array}{lllllll}3 & 1 & 1 & 1 & 3\end{array}$
(3 $\left.2 \begin{array}{lllll} & 1 & 9 & 1 & 2\end{array}\right)$

Örnek 10a. Manfred Senfonisi Op.58, Ölçü 59, artikülasyon egzersizi (Ersoy, 2021).

Örnek 10'da görülen Sol telindeki bu pasajda, 2 ayrı duate görülmektedir. İlk duate örneğinde, ilk 2 notada 1. parmak kullanılmıştır. Serilik gerektiren bir pasaj olduğu için 1. parmağın diğer notaya geçerken kuvvetli ve emin bir şekilde geçmesi gerekmektedir. $\mathrm{Bu}$ tür çeviklik gerektiren gam türü pasajlarda en önemli husus, vuruş başına denk gelen ilk 
notayı daha iyi hissederek basmaktır. Yani aradaki notaları tek tek düşünmek yerine gam pasajının tümünü kapsayan el pozisyonu düşünülmelidir. İkinci duate örneğinde ise pus kullanarak (baş parmak), parmakları gereğinden fazla hareket ettirmeden serilik sağlanabilecektir (Örnek 10a). Bu egzersiz ile, çıkıcı kromatik pasajlarda, artikülasyon açısından parmaklar kuvvetlendirilmiş olacaktır.
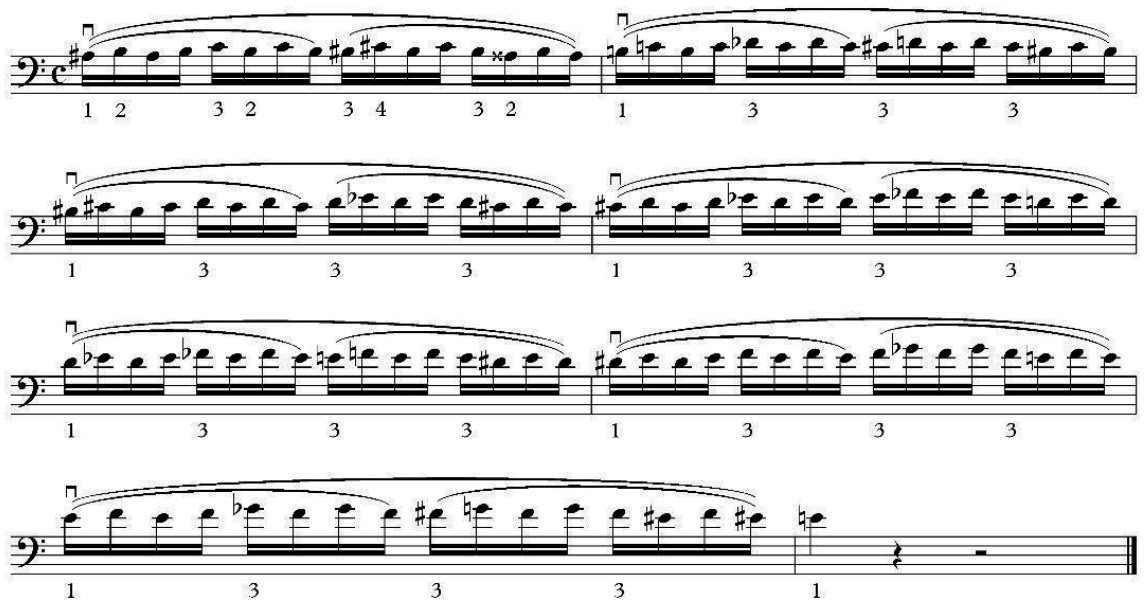

Örnek 11. 2.-3.-4. parmakların artikülasyon açısından çıkıcı ve inici yönde ilerleyen pasajlarda kuvvetlendirilmesine yönelik kromatik egzersiz örneği (Ersoy, 2021).
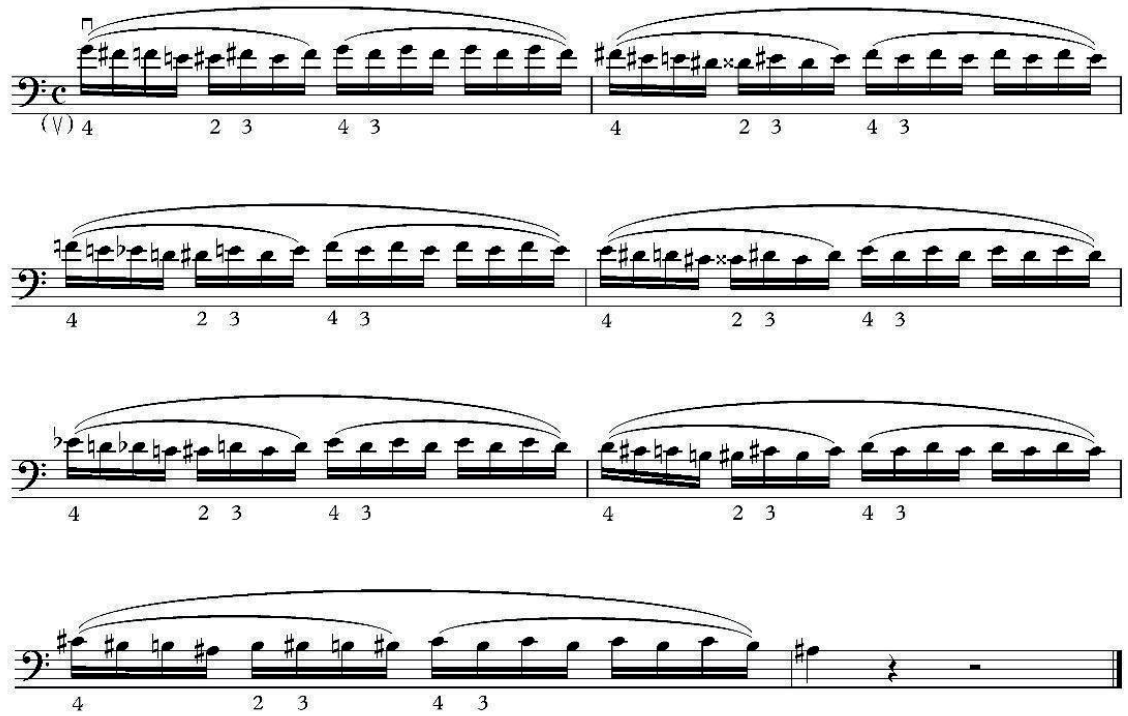

Örnek 12. 2. ve 3. parmakların çıkıcı yönde, 4. ve 3. parmakların inici yönde ilerleyen pasajlarda kuvvetlendirilmesine yönelik egzersiz örneği (Ersoy, 2021). 

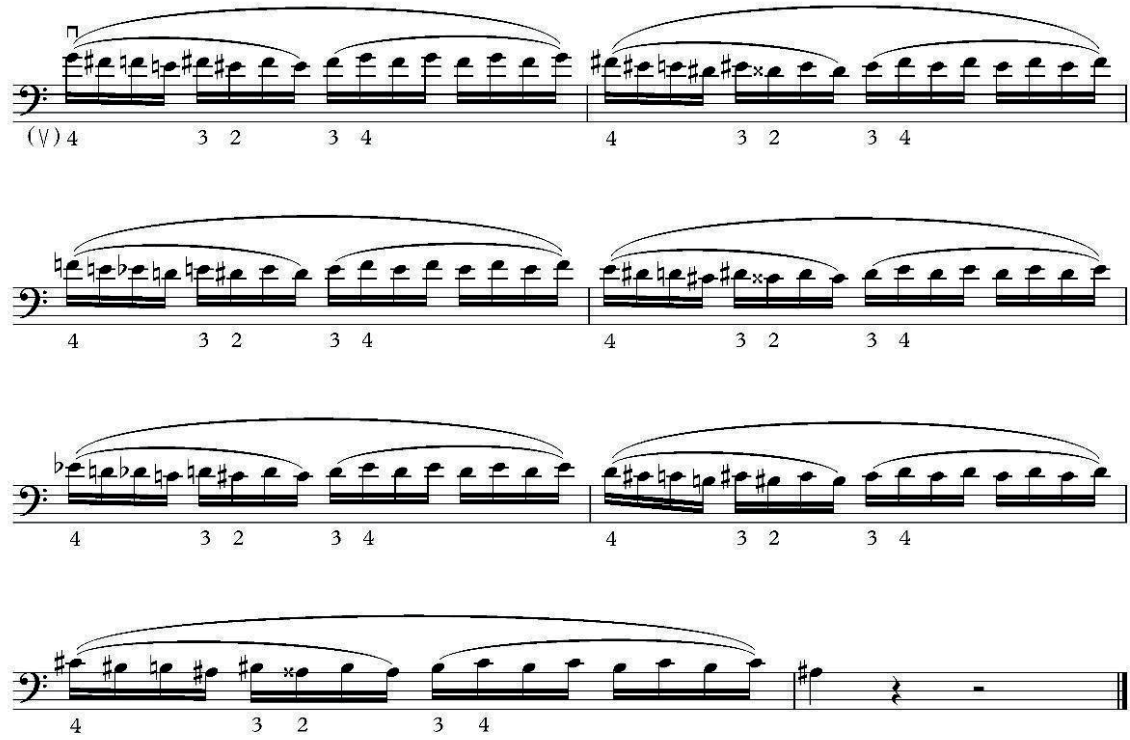

Örnek 13. 3. ve 2. parmakların inici yönde, 3. ve 4. parmakların çıkıcı yöndeki pasajlarda kuvvetlendirilmesine yönelik egzersiz örneği (Ersoy, 2021).
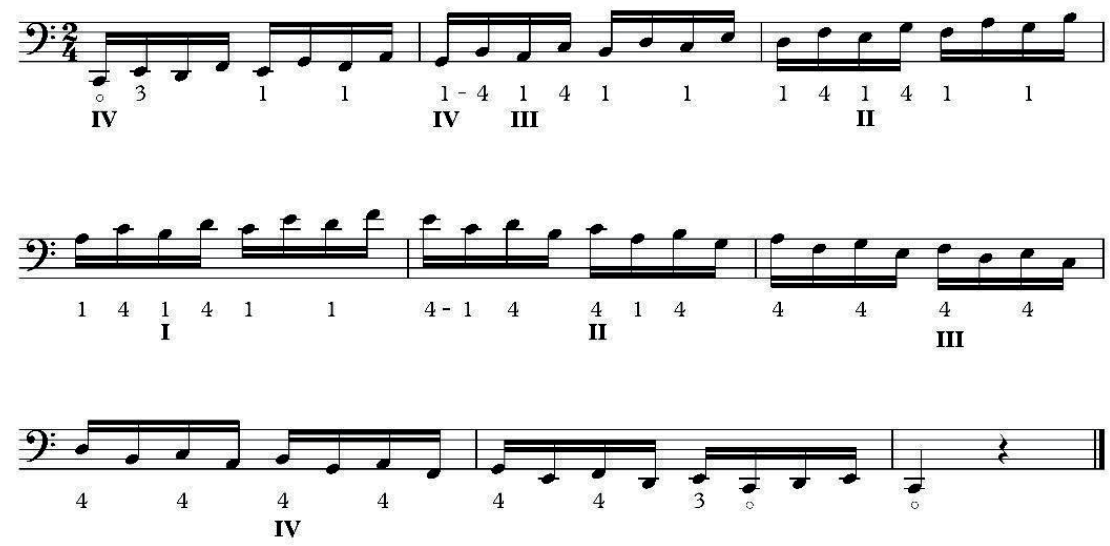

Örnek 14. Sol el 1. parmağın çıkıcı yönde, 4. parmağın inici yönde pozisyon geçişini kuvvetlendirmeye yönelik egzersiz örneği (Ersoy, 2021). 

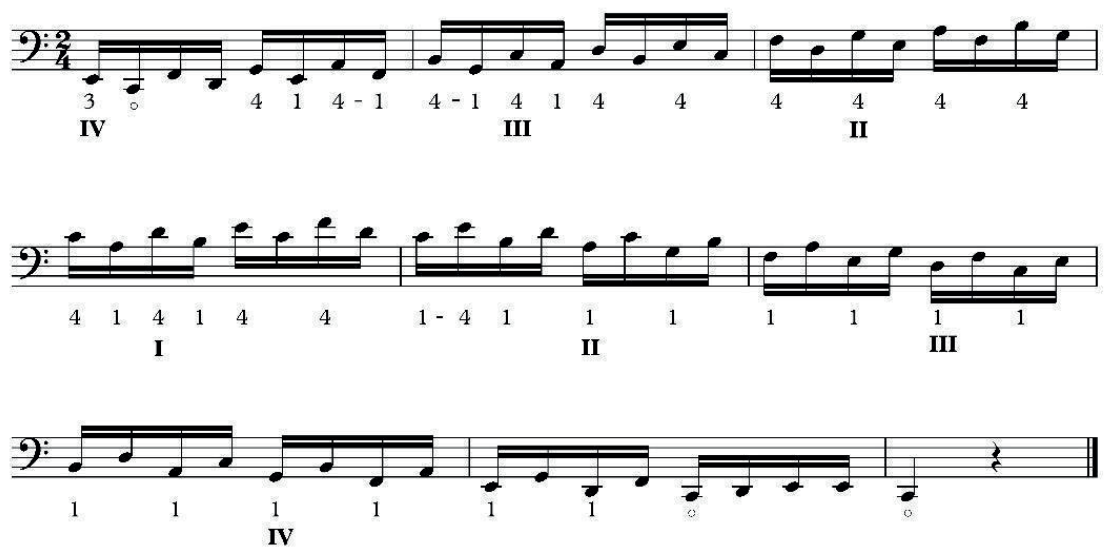

Örnek 15. Sol el 4. parmağın çıkıcı yönde, 1. parmağın inici yönde pozisyon geçişini kuvvetlendirmeye yönelik egzersiz örneği (Ersoy, 2021).

\section{Sonuç ve Öneriler}

Sol el 3. ve 4. parmakların tendonlarının aynı olması nedeniyle, art arda gelen hizlı bir pasajda, parmakların ajilite yönünden zorluk yaşadığı görülmektedir. Bu durum güçsüzlükten ziyade, yapısal özelliklerden kaynaklanmaktadır. Öncelikle icra öncesi bu parmakları çalıştırmaya yönelik egzersizlerle kuvvetlendirip, icra aşamasına geçiş sağlanmalıdır. Bunun için yukarıda bahsedilen tekniklerden de yararlanılarak stres ve gerginliği kontrol edebilme yetisi kazanılmış olacaktır. Tchaikovsky'nin Manfred ve 4. Senfonileri’nin viyolonsel partisindeki hızlı pasajlarda görülen teknik problemleri çözmeye yönelik önerileriler, aşağıda belirtilmiştir.

a) Vücut duruşunu koruyarak, kasları germeden parmakların kontrolü sağlanmalıdır.

b) İcracı ön kolun ağırlı̆ğ yerine parmakların ağırlığını eşit olarak kullanarak pasajın hissettirdiği ruhsal ve fiziksel gerginliği azaltmalıdır. Bunun için ajilite gerektiren pasajlarda kişinin öncelikle zihinsel olarak hazır olması gerekmektedir.

c) Ajilite gerektiren pasajlarda, tuşun üzerindeki sol el parmakları yatay olarak değil, bükülü ve yuvarlak duracak şekilde tutulmalı, (pozisyonun gerektirdiği duruş kombinasyonuna göre) böylece uzunluk açısından eşit olmayan parmaklar yaklaşık olarak aynı konuma gelerek istenilen hıza ulaşılması sağlanmalıdır. 
d) İcracı, parmakları tek tek çalmayı düşünmek yerine, pozisyonu düşünüp çaldığı takdirde, pasajı çok daha rahat ve temposunda çalabilecektir.

e) Ajilite kullanımının yoğun olduğu pasajlarda, parmaklarda büyük artikülasyon yapmadan, tuşa yakın tutularak pozisyon kalıbının takip edilmesi gerekmektedir.

f) Hızlı pasajlarda yaşanan fiziksel ve ruhsal gerginlikleri önlemek için düzenli olarak pozisyon geçişleri ile ilgili egzersizler çalışılmalıdır.

g) Ajilite gerektiren pasajlarda, doğru duate seçebilme yetisinin geliştirilmesi gerekmektedir. İcra sırasında spontan olarak anlık verilen bir kararla gerçekleşen duate seçimi, istenilen hıza ulaşılmasını engeller. Ajilitenin devamı için bir sonraki pasaja uygun gelecek şekilde duate seçimi yapılmalıdır.

h) Sol elde yaşanılan sıkıntı, asla sağ ele (arşe'ye) yansımamalıdır. Farklı arşe tekniklerinin kullanıldığı hızlı pasajlarda öncelikle sol el parmakları, pizzicato çalışması ile kuvvetlendirilmeli ve sonrasında arşe ile çalışmaya devam edilmelidir.

Sonuç olarak icra aşamasında stres ve gerginliği önlemek için, öncelikli olarak yukarıda bahsedilen hususları fiziksel ve ruhsal farkındalık yaratması bakımından özümseyerek, beyin ile parmaklar arasındaki koordinasyon sağlanmalıdır. İcra aşamasında ilgili metotlardan örnekler ile makale yazarının örneklerinden yararlanılabilir.

Teşekkür: Değerli Senem Acar ve Atilla Cömert'e çalışmalarımdaki katkılarından dolayı müteşekkirim.

\footnotetext{
Hakem Değerlendirmesi: Dış bağımsız.

Çıkar Çatışması: Yazar çıkar çatışması bildirmemiştir.

Finansal Destek: Yazar bu çalışma için finansal destek almadığını beyan etmiştir.

Peer-review: Externally peer-reviewed.

Conflict of Interest: The author has no conflict of interest to declare.

Grant Support: The author declared that this study has received no financial support.
}

\section{Kaynakça/References}

Ak Güven, G. (2020). Anatomi 2. hareket sistemi: kaslar. Gürsel Ak Güven’a ait 2020-2021 Güz Yarıyll OMÜ Anatomi ders notları (ppt). 19 Mayıs Üniversitesi Sağlık Hizmetleri Meslek Yüksekokulu, Samsun. Erişim adresi: https://docplayer. biz.tr/197558250-Omu-shmyo-anatomi-2-hareket-sistemi-kaslar-systema-musculare-ogr-gor-dr-gursel-ak-guven.html

Bingöl, N. (2020). Kas anatomisi. Nurhan Bingöl'e ait 2019-2020 Bahar Yarıyılı Kas Anatomisi dersi notları. Ankara Üniversitesi, Tıp Fakültesi Açık Ders Malzemeleri, Ankara. Erişim adresi: https://acikders.ankara.edu.tr/ pluginfile.php/2935/mod_resource/content/0/4.\%20Hafta\%20Kas\%20Sistemi.pdf 
Bursal, M. B. (2019). Hacettepe Üniversitesi Ankara Devlet Konservatuvarı örnekleminde viyolonsel icra tekniğine bağll gelişebilecek fizyolojik rahatsızlıklar (Yayımlanmamış Yüksek Lisans Tezi). Hacettepe Üniversitesi Ankara Devlet Konservatuvarı, Ankara.

Çilden, Ş. (2003, Ekim). Çalgı eğitiminde nitelik sorunları. Cumhuriyetimizin 80. Yılında Müzik Sempozyumu’nda sunulan bildiri, 30-31 Ekim 2003, İnönü Üniversitesi, Malatya.

Davidson, R. J., Kabat-Zinn, J., Schumacher, J., Rosenkranz, M., Muller, D. ve Santorelli, S. F. \& Sheridan, J. F. (2003). Alterations in brain immune function produced by mindfulness meditation. Psychosomatic medicine, 65(4), 564-570. doi:10.1097/01.psy.0000077505.67574.e3

Dexter, J. (1996). Meditasyon. İstanbul: Kibele Yayınevi.

Dilekli, B. (2019). Feldenkrais metodunun Meisner oyunculuk metodu kapsamında oyuncunun dinleme ve eyleme kapasitesi üzerine etkisi (Yayımlanmamış Yüksek Lisans Tezi). Kadir Has Üniversitesi, İstanbul.

Feldenkrais, M., ve Beringer, E. (2010). Embodied wisdom: The collected papers of Moshé Feldenkrais. San Diego, Calif: Somatic Resources.

Gökalp, G. (2018). Alexander tekniğinin viyolonsel çalarken uygulanması (Yayımlanmamış Yüksek Lisans Tezi). Yaşar Üniversitesi Sosyal Bilimler Enstitüsü, Sanat ve Tasarım Ana Sanat Dalı, İzmir.

Kar, T. (2012). Enstrüman ĕgitiminin ses eğitimi üzerindeki etkisi (Yayımlanmamış Yüksek Lisans Tezi). İstanbul Üniversitesi Sosyal Bilimler Enstitüsü, Sahne Sanatları Anasanat Dalı, Opera Sanat Dalı, İstanbul.

Kartal, M. (2016). Nefes teknikleri. İstanbul: Ray Yayıncıl1k.

Khalsa, S. ve Gould, J. (2012). Your brain on yoga (Harvard Medical School Guide), Harvard Medical School Guides, Rosetta Books, Harvard.

Osho (2011). Meditasyon, ilk ve son özgürlük. İstanbul: Omega Yayınları.

Schultz, L. H., Uyterhoeven, S. ve Khalsa, S. B. S. (2011). Evaluation of a yoga program for back pain. Journal of Yoga and Physical Therapy, 1(2), 103. doi:10.4172/2157-7595.1000e103.

Simard, A. A. ve Henry, M. (2009). Impact of a short yoga intervention on medical students' health: a pilot study. Medical teacher, 31(10), 950-952.

Stueck, M. ve Gloeckner, N. (2005). Yoga for children in the mirror of the science: Working spectrum and practice fields of the training of relaxation with elements of yoga for children. Early child development and care, 175(4), 371-377.

Tchaikovsky, P.I. (1960). Symphony No.4, Op.36, Final Allegro con fuoco [Musical scores]. Leipzig: Bruckner-Verlag. New York: Reprinted E.F.Kalmus. (Original work published 1888)

Tchaikovsky, P.I. (1933-1970). Manfred Symphony Op.58, 1. Part, Lento lugubre [Musical scores]. First edition (reprint) Moscow: P. Jurgenson. New York First edition: Reprinted E.F. Kalmus. (Original work published 1886)

Tezişçi Özmenay, P. (2018). Alexander tekniğinin temel uygulama ilkeleri ve çalışma yöntemleri. AKÜ Amader, 4(7), 65-80.

Teztel, G. ve Aşkın, C. (2007). Sahne heyecanının Türk müzisyenler arasındaki yaygınlığı ve çözüm yöntemleri. ITÜ̈ dergisi/b Sosyal Bilimler, 4(2), 3-10.

Teztel, G. (2007). Psikolojide akış kuramı ve müzik icrası bağlamında değerlendirilmesi. Konservatoryum, 3(2), 1-17. 
